\title{
Growth, Development, and Water Consumption of Irrigated Bean Crop Related to Growing Degree-Days on Different Soil Tillage Systems in Southeast Brazil
}

\author{
Gerson Araujo de Medeiros, ${ }^{1}$ Luiz Antonio Daniel, ${ }^{2}$ and Felipe Hashimoto Fengler ${ }^{1}$ \\ ${ }^{1}$ Universidade Estadual Paulista (UNESP), Campus de Sorocaba, Avenida Três de Março 511, 18087-180 Sorocaba, SP, Brazil \\ ${ }^{2}$ Faculdade de Tecnologia de Indaiatuba (FATECID), Rua Dom Pedro I, 65 Cidade Nova I, 13334-100 Indaiatuba, SP, Brazil \\ Correspondence should be addressed to Gerson Araujo de Medeiros; gerson@sorocaba.unesp.br
}

Received 20 November 2015; Accepted 22 May 2016

Academic Editor: David Clay

Copyright (C) 2016 Gerson Araujo de Medeiros et al. This is an open access article distributed under the Creative Commons Attribution License, which permits unrestricted use, distribution, and reproduction in any medium, provided the original work is properly cited.

\begin{abstract}
Degree-days may be an alternative for predicting the influence of temperature on physiological aspects of plants in a changing climate. The objective of this research was to evaluate the relation between cumulative degree-days index $\left(\sum G\right)$ and the development, growth, and water consumption of irrigated bean under different soil tillage systems (STS). We developed an experiment in Southeast Brazil in plots managed with the following STS: chisel ploughing (CP), disk ploughing (DP), and revolving hoe $(\mathrm{RH})$. The treatments did not influence the crop phenology when correlated to $\sum G$. The parameters of canopy ground cover, leaf area index, total dry matter, and the plant height presented a highly significant relationship with $\sum G(P<0.05)$. We also compared the results of field water balance with a simulation developed between the crop coefficient and $\sum G$ and found a strong relationship $\left(R^{2}=0.93^{* *} ; * *\right.$ : high statistical significance $\left.(P<0.01)\right)$ between these measurements and the model. The total water consumption measured at the irrigated bean crop reached $383 \mathrm{~mm}, 386 \mathrm{~mm}$, and $375 \mathrm{~mm}$ while that simulated from dual crop coefficient approach based on $\sum G$ reached $378 \mathrm{~mm}, 373 \mathrm{~mm}$, and $349 \mathrm{~mm}$ to CP, DP, and $\mathrm{RH}$, respectively, representing a mean difference of $4.2 \%$.
\end{abstract}

\section{Introduction}

Since crop growth, development, and water consumption are strongly influenced by temperature [1-4] climate change has increased the vulnerability of the emerging, like Brazil, which is highly dependent on agricultural production.

This strong relationship has led to the dissemination of the thermal units concept, expressed in degree-days, to describe and forecast the phenological stages and length of growing season for several crops. This index is preferred to other approaches, such as the number of days after the emergence or sowing, and represents the cumulative amount of heat necessary for a particular crop to develop $[4,5]$.

There are different applications of the cumulative growing degree-days approach $\left(\sum G\right)$ or thermal units. For example, we can forecast the growing season length and how it may be influenced by climate change $[5,6]$, plan for the growing season [7], forecast potential production of the crop [6], compute subroutines in mathematical models [8], and estimate crop water consumption and irrigation management [1, 7, 9-12].

Different factors can influence the relationship degreedays and plant growth and development. These include temperature variation $[2,5]$, nutrients and plant management $[1$, $2,13]$, the cultivar $[7,8]$, and water availability [2]. However, there is a lack of studies on the influence of soil tillage system on relationship between thermal sum and the development, vegetative growth, and water demand of irrigated crops.

In this context, we introduce the bean crop, an important protein source to human consumption. In 2013, the global production reached 22.8 million tons, with Myanmar (3.7 million tons), India (3.6 million tons), Brazil (2.9 million tons), Mexico (1.3 million tons), and United Republic of 
Tanzania (1.1 million tons) comprising the top five dry beans production countries in the world FAO [14].

This crop is vulnerable to the variation of mesological factors, demanding the development and testing of empirical relations to forecast its performance considering the year-toyear variability of temperature.

Therefore, in this research, we evaluated the development, growth, and water consumption of irrigated bean (Phaseolus vulgaris $\mathrm{L}$.) based on cumulative growing degree-days, under different soil tillage systems in Southeast Brazil.

\section{Material and Methods}

We carried out this research at Faculdade de Engenharia Agrícola from Universidade Estadual de Campinas (UNICAMP), in Campinas city, São Paulo state, Brazil, $47^{\circ} 05^{\prime} \mathrm{W}$, $22^{\circ} 54^{\prime} \mathrm{S}$, and $606 \mathrm{~m}$ above sea level. The soil is an oxisoil, known as red Latosol, clay texture $\left(550 \mathrm{~g} \mathrm{~kg}^{-1}\right)$, with a mean saturated hydraulic conductivity of $70 \mathrm{~mm} \mathrm{~h}^{-1}$ and a ground slope of $0.09 \mathrm{~m} \mathrm{~m}^{-1}$ [15].

In 1985, eight experimental plots were initiated for measurements of soil and water loss. Each experimental plot had an area of $600 \mathrm{~m}^{2}$ (20 m wide by $30 \mathrm{~m}$ long) and a collector of $20 \mathrm{~m}$ wide. From 1986 to 1990, the soil was recovered to introduce different agricultural mechanization treatments. In the period from 1990 to 1998, only maize was cropped in the plots during the rainy season (November to February) [16]. In September 1999, we introduced irrigated dry bean (Phaseolus vulgaris $\mathrm{L}$.), cv. IAC Carioca, a bush bean with indeterminate growth habit, less than $0.4 \mathrm{~m}$ depth of effective root system, and the total duration of growth varying from 90 to 95 days.

The continued use of these tillage systems for eight years influenced various soil physical and chemical parameters, as reported by de Medeiros et al. [15, 16]. This influence has guided the selection of the following soil tillage systems to be analyzed in this research [16]:

(a) Chisel ploughing system (CP): $0.30 \mathrm{~m}$ depth, followed by a light disc harrowing.

(b) Disk ploughing system (DP): three reversible disk plough operations $26^{\prime \prime}$ incorporated crop residues to $0.20 \mathrm{~m}$ deep. At the time of sowing, a second ploughing was carried out at $0.25 \mathrm{~m}$ depth, followed by a light disk harrowing.

(c) Revolving hoe system ( $\mathrm{RH})$ : single soil tillage was carried out with a revolving hoe to $0.18 \mathrm{~m}$ deep, to incorporate crop residues.

On August 27th, 1999, we started the soil tillage and on August 31st the seeding and fertilization, with a population density of 25 plants $\mathrm{m}^{-2}$. The emergence was on September 7 th and the harvest on November 30th or at 84 days after emergence (DAE) in all plots.

During the whole season, $203 \mathrm{~mm}$ of rainfall accumulated, the mean temperature was $22^{\circ} \mathrm{C}$, and the mean reference evapotranspiration $\left(\mathrm{ET}_{o}\right.$ ) was $430 \mathrm{~mm}$ or $4.7 \mathrm{~mm} \mathrm{~d}^{-1}$, calculated from Penman-Monteith method modified by Food and Agriculture Organization of the United Nations (FAO) [17]. Since the rainfall alone would disallow an economic crop production, we used a drip irrigation system to supply the water needs of the beans.

We applied moderate amounts of irrigation water, which were $251 \mathrm{~mm}, 258 \mathrm{~mm}$, and $232 \mathrm{~mm}$ to CP, DP, and RH tillage systems, respectively. These were distributed in 9 weekly intervals, throughout the whole season. This irrigation, together with the evapotranspiration and rain from meteorological conditions, supported a water balance, assuming no deep percolation and runoff, for most of the season. Average values of water tension at a depth of $0.15 \mathrm{~m}$ were $17 \mathrm{kPa}$ for CP and $14 \mathrm{kPa}$ for DP and RH tillage systems in the period of 681 DAE (from September 13th to November 27th), providing similar soil humidity to all treatments.

This work was developed in a thermic time based on cumulative growing degree-days, calculated in the following way $[1,10]$ :

$$
\sum G=\sum_{i=1}^{n}\left(\frac{\left(T_{\max }+T_{\min }\right)}{2}-T_{\text {base }}\right),
$$

where $\sum G$ is the accumulated growing degree-days $\left({ }^{\circ} \mathrm{C}\right) ; T_{\max }$ is the maximum daily temperature of the air $\left({ }^{\circ} \mathrm{C}\right), T_{\min }$ is the minimum daily temperature of the air $\left({ }^{\circ} \mathrm{C}\right)$, and $T_{\text {base }}$ is that below which the plants cannot grow $\left({ }^{\circ} \mathrm{C}\right)$.

For this study we used $10^{\circ} \mathrm{C}$ for all the crop developing stages, as suggested by other authors for different crops and environmental conditions, including beans $[1,5,6,13]$.

Every day, we monitored the phenological evolution of the crop. The phenological stages evaluated were V0 (seed germination), V2 (seedling emergence), V3 (first trifoliate), V4 (third trifoliate), R5 (pre flowering), R6 (flowering), R7 (pod development), R8 (pod filling), and R9 (ripeness) [18].

Bean growth and development were weekly monitored from the plots prior to harvest, by measuring leaf area (model LI-3000, LI-COR Instruments), height, canopy ground cover (GC), and above ground dry matter (DM). Leaf area index (LAI) was calculated based on measured plant density and GC was measured from the real horizontal projection of the canopy, calculated from images, taken at 1.5 meters above the surface [19].

Measurements of water balance components were carried out from September to November of 1999, when we calculated the actual evapotranspiration from the following equation [19]:

$$
\Delta S=(P+I+U)-(R+D+\mathrm{ET}),
$$

where $\Delta S$ is the variation of water stored in the root zone $(\mathrm{mm}), P$ is the rainfall $(\mathrm{mm}), I$ is the irrigation depth $(\mathrm{mm})$, $U$ is the upward capillary flow into the root zone from below $(\mathrm{mm}), R$ is the runoff $(\mathrm{mm}), D$ is the downward drainage out of the root zone ( $\mathrm{mm})$, and ET is the water lost by evapotranspiration $(\mathrm{mm})$.

We measured soil water content profiles gravimetrically in the top $0.50 \mathrm{~m}$ twice a week, in the plots. We estimated the upward and downward capillary using Darcy's law as described by de Medeiros et al. [15]. Soil water tension was monitored by tensiometers in $0.15 \mathrm{~m}, 0.30 \mathrm{~m}$, and $0.50 \mathrm{~m}$ depth, while daily meteorological data was obtained from 
an automated weather station located $100 \mathrm{~m}$ far from the experimental site.

We used the dual crop coefficients approach to simulate the water consumption by plants and compared to that measured in the water balance, as follows [17]:

$$
k_{c}=k_{\mathrm{cb}} \cdot k_{a}+k_{s}
$$

where $k_{c}$ is the crop coefficient, $k_{\mathrm{cb}}$ is the basal crop coefficient, $k_{a}$ is a coefficient dependent upon available soil moisture (in this study we considered $k_{a} 1.0$ ), and $k_{s}$ is a coefficient to adjust for increased surface soil evaporation which occurs after rain or irrigation. Consider

$$
\mathrm{ET}_{\text {sim }}=k_{c} \cdot \mathrm{ET}_{o} \text {, }
$$

where ET is the simulated crop evapotranspiration $(\mathrm{mm}), k_{c}$ is the crop coefficient, and $\mathrm{ET}_{o}$ is the grass reference evapotranspiration ( $\mathrm{mm})$.

We developed equations relating $k_{\mathrm{cb}}$ to accumulated growing degree-days $\left(\sum G\right)$, based on previous works $[1,19-$ 22].

\section{Results and Discussions}

3.1. Bean Crop Development as Related to Cumulative Growing Degree-Days. We observed that the bean crop development was independent of the soil tillage system, allowing the use of one thermal time scale for predicting phenological events (Table 1). The harvest of all treatments occurred when it reached $1,114 \sum G$.

When comparing this result to those obtained by other researchers, we considered only works that adopted, over the whole cycle, the base temperature of $10^{\circ} \mathrm{C}$, as reported by de Medeiros et al. [1] and Tisot et al. [13].

With the same variety, others have found similar results. For example, Tisot et al. [13] in Piracicaba city, state of São Paulo, Brazil, reported a total of $1,158 \sum G$ during the whole crop cycle. de Medeiros et al. [1] reported 1,170 growing degree-days from the emergence to the harvest.

Flowering, corresponding to R6 stage [18], occurred at $504 \sum G$, very close to that obtained by [1], for the same variety under irrigating conditions, when it was accumulated for 532 growing degree-days. Tisot et al. [13], in turn, found $666 \sum G$ for the same phenological stage.

Shortly after flowering in the present study, the bean crop reached $100 \%$ GC. Unlike flowering, this event differed among tillage treatments. For the treatments CP and DP, full ground cover was reached at $578 \sum G$, which was $41 \mathrm{DAE}$ (October 18th), agreeing with [10]. As for the crop sown at $\mathrm{RH}$ plot, $100 \%$ of GC did not occur until 47 DAE (October 24th), when it had accumulated for 652 growing degree-days, and was at the end of flowering and beginning of the pod development (R7).

This result is closer to that obtained by [1], observing $100 \%$ of GC for bean crops sown under a planting density of 28 plants $\mathrm{m}^{-2}$, when it was reached around $650 \sum G$.

After the full ground cover, the bean crop flowering continued to expand, so that the maximum LAI occurred
TABLE 1: Thermal time of bean crop phenological stages, cv. IAC Carioca, in Campinas city, São Paulo state, Brazil.

\begin{tabular}{lccc}
\hline Phenological stage & $\sum G$ & Phenological stage & $\sum G$ \\
\hline V0 & 15 & R5 & 431 \\
V1 & 102 & R6 & 504 \\
V2 & 145 & R7 & 616 \\
V3 & 176 & R8 & 695 \\
V4 & 271 & R9 & 897 \\
\hline
\end{tabular}

TABle 2: First degree equation $(Y=A+B X)$ relating the accumulated dry matter of the bean crop $\left(\mathrm{g} \mathrm{m}^{-2}\right)$ to the thermal time (degree-days) for soil tillage systems (STS): chisel ploughing (CP), disk ploughing (DP), and revolving hoe (RH), during the linear growth stage, in Campinas city, São Paulo state, Brazil.

\begin{tabular}{lcccccc}
\hline STS & $A$ & $B$ & LL & UL & $R^{2}$ & $n$ \\
\hline CP & -371.36 & 0.98 & 0.73 & 1.24 & $0.97^{* *}$ & 6 \\
DP & -319.57 & 0.87 & 0.49 & 1.24 & $0.91^{* *}$ & 6 \\
RH & -337.01 & 0.88 & 0.39 & 1.37 & $0.86^{* *}$ & 6 \\
\hline
\end{tabular}

LL: lower limit of confidence interval of the gradient line $B$ at the level of 95\%; UL: upper limit of the confidence interval of the gradient line $B$ at the level of $95 \% ; R^{2}$ : determination coefficient; $n$ : number of observations.

at 51 DAE (October 28th), reaching 4.5 and 3.6 for the $\mathrm{CP}$ and $\mathrm{RH}$ treatments, respectively, at $695 \sum \mathrm{G}$. This also marked the beginning of pod filling (R8). For the crop sown at DP tillage system, the maximum LAI reached 3.4, at 58 DAE (November 4 th), or $793 \sum G$, during the R8 stage, very close to that obtained by [1], for the same variety, at $812 \sum G$.

At the same time maximum LAI was achieved, maximum plant height of $0.49 \mathrm{~m}, 0.48 \mathrm{~m}$, and $0.44 \mathrm{~m}$ for the soil tillage systems CP, DP, and RH was measured, respectively.

Dry matter (DM) production was different among the treatments, since the chisel ploughing and revolving hoe tillage systems accumulated their maximum amounts of 509.9 and $522.3 \mathrm{~g} \mathrm{~m}^{-2}$, respectively, at $65 \mathrm{DAE}\left(877 \sum G\right)$, during the pod filling (R8). In disk ploughing treatment, maximum accumulated DM reached $488.1 \mathrm{~g} \mathrm{~m}^{-2}$ on the harvest day, at $83 \mathrm{DAE}\left(1,114 \sum G\right)$. de Medeiros et al. [1] observed a maximum accumulation of bean crop dry matter, cv. IAC-Carioca, of $601.5 \mathrm{~g} \mathrm{~m}^{-2}$ at $57 \mathrm{DAE}$, or $950 \sum \mathrm{G}$.

3.2. Bean Crop Growth as Related to Cumulative Growing Degree-Days. Table 2 shows the relations that describe the dry matter evolution as a function of the accumulated thermal sum, at the bean crop linear growth stage.

The average growth rate of the crop at the growth linear phase, from 31 to $65 \mathrm{DAE}$, equivalent to thermal time from 442 to $877 \sum G$, was higher at the $\mathrm{CP}$ treatment, reaching $0.98 \mathrm{~g} \mathrm{~m}^{-2}$ degree-days ${ }^{-1}$. RH and DP treatments achieved 0.88 and $0.87 \mathrm{~g} \mathrm{~m}^{-2}$ degree-days ${ }^{-1}$, respectively; however the slope coefficients for linear regression should not be considered different for the soil tillage systems, according to F-distribution (Table 2), since at 95\% of significance level the lower and upper limit have overlapping values for all treatments. 
TABLE 3: Polynomial equations $\left(Y=\beta_{0}+\beta_{1} X+\beta_{2} X^{2}+\beta_{3} X^{3}\right)$ relating the bean crop growth parameters to thermal time (degree-days accumulated), for each soil tillage system (STS): chisel ploughing $(\mathrm{CP})$, disk ploughing (DP), and revolving hoe $(\mathrm{RH})$, and considering all STS as a single data set (All), in Campinas city, São Paulo state, Brazil.

\begin{tabular}{lcccccc}
\hline STS & $\beta_{0}$ & $\beta_{1}$ & $\beta_{2}$ & $\beta_{3}$ & $n$ & $R^{2}$ \\
\hline \multicolumn{7}{c}{ Vegetal coverage percentage $(\%)$} \\
CP & 109.5 & -0.716 & $1.92 \times 10^{-3}$ & $-1.26 \times 10^{-6}$ & 11 & $0.97^{* *}$ \\
RH & 114.5 & -0.803 & $2.05 \times 10^{-3}$ & $-1.31 \times 10^{-6}$ & 12 & $0.97^{* *}$ \\
DP & 116.2 & -0.763 & $1.99 \times 10^{-3}$ & $-1.30 \times 10^{-6}$ & 11 & $0.97^{* *}$ \\
All & 111.1 & -0.745 & $1.95 \times 10^{-3}$ & $-1.27 \times 10^{-6}$ & 34 & $0.95^{* *}$ \\
\hline \multicolumn{7}{c}{ Leaf area index } \\
CP & -3.36 & $1.19 \times 10^{-2}$ & $4.84 \times 10^{-6}$ & $-1.16 \times 10^{-8}$ & 9 & $0.91^{* *}$ \\
RH & -2.30 & $5.43 \times 10^{-2}$ & $1.60 \times 10^{-5}$ & $-1.78 \times 10^{-8}$ & 9 & $0.95^{* *}$ \\
DP & -2.36 & $7.25 \times 10^{-2}$ & $1.04 \times 10^{-5}$ & $-1.37 \times 10^{-8}$ & 9 & $0.96^{* *}$ \\
All & -3.00 & $1.01 \times 10^{-2}$ & $7.27 \times 10^{-6}$ & $-1.28 \times 10^{-8}$ & 27 & $0.93^{* *}$ \\
\hline \multicolumn{7}{c}{ Dry matter (g m $\left.{ }^{-2}\right)$} \\
CP & 183.7 & -1.647 & $4.18 \times 10^{-3}$ & $-2.20 \times 10^{-6}$ & 11 & $0.98^{* *}$ \\
RH & 126.6 & -1.145 & $2.95 \times 10^{-3}$ & $-1.45 \times 10^{-6}$ & 11 & $0.95^{* *}$ \\
DP & 142.7 & -1.295 & $3.35 \times 10^{-3}$ & $-1.71 \times 10^{-6}$ & 11 & $0.97^{* *}$ \\
All & 153.4 & -1.383 & $3.54 \times 10^{-3}$ & $-1.82 \times 10^{-6}$ & 33 & $0.96^{* *}$ \\
\hline \multicolumn{7}{c}{ Plant height (cm) } \\
CP & 16.00 & -0.0927 & $4.15 \times 10^{-4}$ & $-3.08 \times 10^{-7}$ & 9 & $0.99^{* *}$ \\
RH & 27.55 & -0.173 & $5.38 \times 10^{-4}$ & $-3.67 \times 10^{-7}$ & 9 & $0.98^{* *}$ \\
DP & 27.17 & -0.156 & $5.21 \times 10^{-4}$ & $-3.65 \times 10^{-7}$ & 9 & $0.99^{* *}$ \\
All & 23.57 & -0.141 & $4.91 \times 10^{-4}$ & $-3.47 \times 10^{-7}$ & 27 & $0.96^{* *}$ \\
\hline
\end{tabular}

These results were superior to the ones found by [1] for beans, obtaining 0.73 and $0.84 \mathrm{~g} \mathrm{~m}^{-2}$ degree-days ${ }^{-1}$, for population density of 14 and 28 plants $\mathrm{m}^{-2}$, respectively.

Table 3 presents the relations obtained between the growth parameters evaluated and the accumulated growing degree-days index.

The adjusted curves show the high significance level of the obtained relations $(P<0.05)$, agreeing with the results of [1], who had already found highly significant polynomial relations among GC, LAI, and DM, with $\sum G$ for the irrigated bean crop. However, the relative differences of crop growth performance observed in this study were not reflected in the equation parameters presented in Table 3. Thus, it was possible to use a single equation to describe the evolution of each growth index evaluated based on the accumulated growing degree-days for the irrigated bean crop submitted to different soil tillage systems.

3.3. Water Consumption of Beans as Related to Cumulative Growing Degree-Days. We estimated daily evapotranspiration for irrigated bean crop from dual crop coefficient approach (3) and grass $\mathrm{ET}_{o}$ reference (4). To plot $k_{c}$ curves we followed the FAO classification of phenological stages and that proposed by [18], both using thermal units, as follows.

3.3.1. Initial Period, Corresponding to Phenological Stages from $V 0$ to V4 (15 to $272 \sum G$ ). In this period, $k_{\mathrm{cb}}$ is constant and independent of crop growth, because it is strongly influenced by spectral soil characteristics as albedo [17]. de Medeiros and Arruda [20] measured a mean $k_{\mathrm{cb}}$ of 0.38 for red Latosol in compensation lysimeters, adapted and tested to represent the necessary conditions to estimate $k_{\mathrm{cb}}$, that is, full water supply for plant growth and dry soil surface.

3.3.2. Crop Development Period, Corresponding to Phenological Stages from V4 to R8 (272 to $\left.695 \sum G\right)$. Significant relations between $k_{\mathrm{cb}}$ and crop growth parameters have been observed in different crops $[10,11,19,21,23]$. During the bean crop season we estimated daily LAI for each soil tillage system using the single equation presented in Table 3 , as follows:

$$
\begin{aligned}
\text { LAI }= & -3.00+1.01 \times 10^{-2}\left(\sum G\right)+7.27 \\
& \times 10^{-6}\left(\sum G\right)^{2}-1.28 \times 10^{-8}\left(\sum G\right)^{3} .
\end{aligned}
$$

We calculated daily basal crop coefficient for bean crop from the following equation developed by de Medeiros et al. [19]:

$$
\begin{aligned}
k_{\mathrm{cb}}= & 0.367-1.44 \times 10^{-2}(\mathrm{LAI})+0.206(\mathrm{LAI})^{2}-4.29 \\
& \times 10^{-2}(\mathrm{LAI})^{3}
\end{aligned}
$$

After that, we derived a relationship to estimate daily $k_{\mathrm{cb}}$ based on accumulated growing degree-days for the crop development period, as follows:

$$
\begin{aligned}
k_{\mathrm{cb}}= & 2.25-1.57 \times 10^{-2}\left(\sum G\right)+4.02 \times 10^{-5}\left(\sum G\right)^{2} \\
& -2.91 \times 10^{-8}\left(\sum G\right)^{3}, \quad n=18, R^{2}=0.97^{* *}
\end{aligned}
$$

3.3.3. Mid-Season Period, Corresponding to Phenological Stages from $R 8$ to $R 9$ (695 to $807 \sum G$ ). In this period, we adopted $k_{\mathrm{cb}}$ equal to 1.2 when the crop reached full ground cover and it was independent of crop growth, following the recommendation of $[9,10,12,19,22,23]$.

3.3.4. Late Season Period, Corresponding to Phenological Stages from R9 to Harvest (807 to $1114 \sum G$ ). We measured LAI for each treatment during the late season period, when the crop begins the senescence. From these measurements we estimated $k_{\mathrm{cb}}(7)$. After that, we derived the following equation to estimate daily $k_{\mathrm{cb}}$ to all treatments, during the late season:

$$
\begin{aligned}
k_{\mathrm{cb}}= & -0.98+5.87 \times 10^{-3}\left(\sum G\right)+4.23 \\
& \times 10^{-6}\left(\sum G\right)^{2}, \quad n=9, R^{2}=0.98^{* *} .
\end{aligned}
$$

Based on the pattern of red Latosol surface drying and according to de Medeiros et al. [19], we adopted $k_{c}$ equal to 1.2 during the rain or irrigation event and on the following day. Figure 1 shows the simulated crop curve for irrigated bean crop under different soil tillage systems where one can see the "spikes" in the $k_{c}$ curve due to the increased evaporation of wet soil [23].

We evaluated the performance of crop coefficient estimates based on $\sum G$ to predict daily water consumption of an 


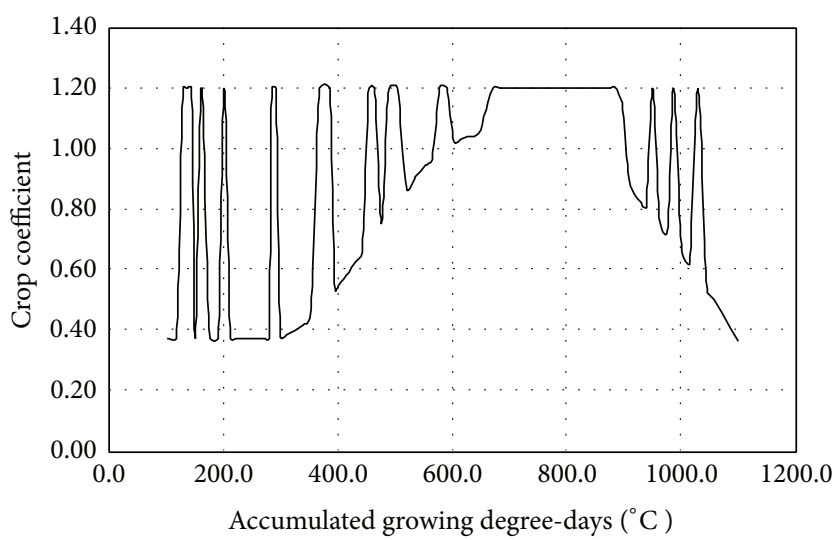

(a)

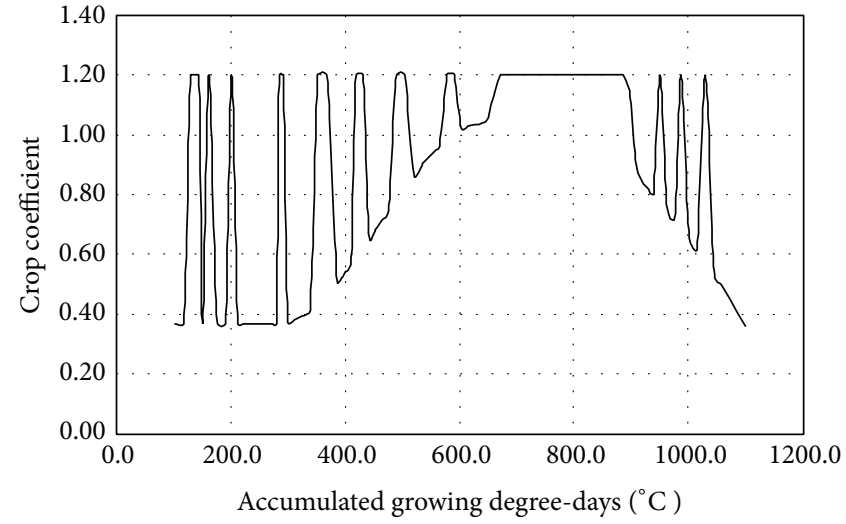

(b)

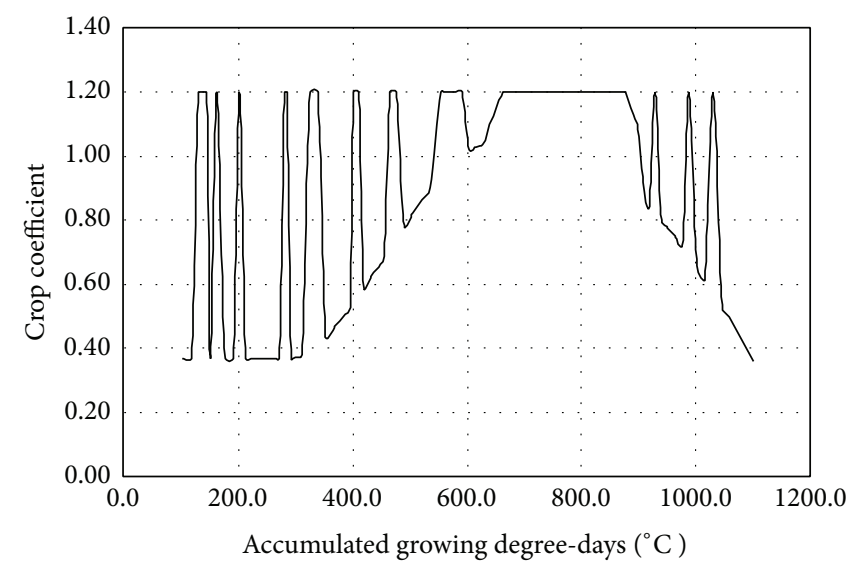

(c)

FiguRE 1: Crop coefficient curve for bean crop sown in the following soil tillage systems treatments: (a) revolving hoe, (b) disk ploughing, and (c) chisel ploughing, in Campinas city, São Paulo state, Brazil.

irrigated field area managed under different soil tillage systems. Figure 2 presents a comparison between the simulated evapotranspiration based on crop curve (Figure 1) and that determined from water balance under field conditions. From this figure it was possible to derive the following equation:

$$
\mathrm{ET}_{\text {sim }}=1.26+0.94 \cdot \mathrm{ET}, \quad n=35, R^{2}=0.93^{* *},
$$

where $\mathrm{ET}_{\text {sim }}$ is the simulated crop evapotranspiration (mm) and ET is the observed crop evapotranspiration $(\mathrm{mm})$.

We can see the strong linear relationship $(P<0.01)$ between simulated and observed evapotranspiration, which was corroborated when comparing the total observed evapotranspiration (2) and that predicted. In the field ET reached $384 \mathrm{~mm}, 387 \mathrm{~mm}$, and $375 \mathrm{~mm}$ and that simulated was $378 \mathrm{~mm}, 373 \mathrm{~mm}$, and $349 \mathrm{~mm}$ to $\mathrm{CP}, \mathrm{DP}$, and $\mathrm{RH}$, respectively, representing a mean difference of $4 \%$.

These results confirm that the use of dual crop coefficient (related to accumulated growing degree-days) and the grass reference evapotranspiration allowed a transferable way to predict water consumption for irrigated bean crop, independent of tillage system.

Finally, the main results of this study suggest that irrigated bean crop development, growth, and water consumption are

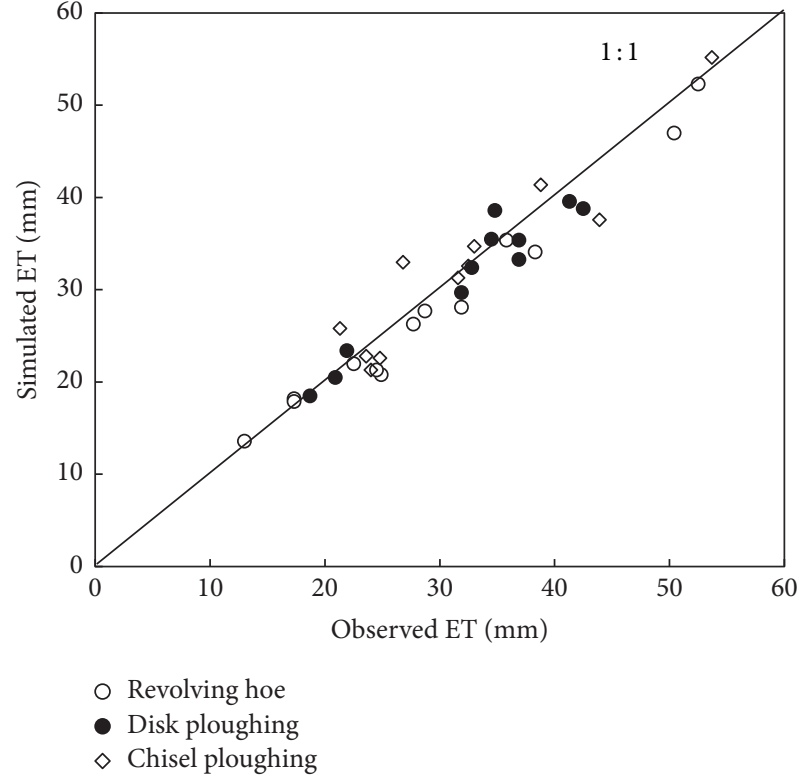

FIGURE 2: Observed and simulated evapotranspiration determined from dual crop coefficient related to degree-days, for bean crop sown in different soil tillage systems treatments. 
very similar among the different soil tillage systems. One of the possible causes was the drip irrigation system that provided high water application efficiency and that reduced water tension on the soil profile during all the trial. These characteristics decrease the effects caused by the soil tillage systems over eight years, mainly at soil physical parameters, like bulk density. In the rainy season the effect of soil tillage systems on the crop performance is much more evident, as reported by de Medeiros et al. [16].

\section{Conclusion}

The phenological stages of irrigated bean crop were independent of the soil tillage system.

Chisel ploughing had superior GC, LAI, and DM compared to others.

The relations between crop growth parameters and accumulated growing degree-days were highly significant; however there was no statistical difference among tillage systems. Therefore, it was possible to use a single equation to forecast each crop growth parameter based on accumulated growing degree-days for irrigated beans, regardless of soil tillage systems.

Dual crop coefficients approach based on accumulated growing degree-days for irrigated bean crop allowed forecasting the total water consumption under distinct soil tillage systems. The mean difference between measured and estimated values of total evapotranspiration reached $4 \%$.

\section{Competing Interests}

The authors declare that there is no conflict of interests regarding the publication of this paper.

\section{Acknowledgments}

The authors thank Fundação de Amparo à Pesquisa do Estado de São Paulo (FAPESP), for the financial support under the Process 1999/03221-9.

\section{References}

[1] G. A. de Medeiros, F. B. Arruda, E. Sakai, M. Fujiwara, and N. R. Boni, "Vegetative growth and bean crop coefficient as related to accumulated growing-degree-days," Pesquisa Agropecuaria Brasileira, vol. 35, no. 9, pp. 1733-1742, 2000.

[2] C.-R. Chiou, T. Y. Hsieh, and C.-C. Chien, "Plant bioclimatic models in climate change research," Botanical Studies, vol. 56, article 26, pp. 1-12, 2015.

[3] D. Zhao and Y.-R. Li, "Climate change and sugarcane production: potential impact and mitigation strategies," International Journal of Agronomy, vol. 2015, Article ID 547386, 10 pages, 2015.

[4] R. S. Poethig, "Phase change and the regulation of developmental timing in plants," Science, vol. 301, no. 5631, pp. 334-336, 2003.

[5] K. Mix, V. L. Lopes, and W. Rast, "Growing season expansion and related changes in monthly temperature and growing degree days in the Inter-Montane Desert of the San Luis Valley, Colorado," Climatic Change, vol. 114, no. 3-4, pp. 723-744, 2012.
[6] B. J. Sun and G. C. Van Kooten, "Weather effects on maize yields in northern China," Journal of Agricultural Science, vol. 152, no. 4, pp. 523-533, 2014.

[7] T. E. Martínez-Cruz, D. C. Slack, K. L. Ogden, and M. Ottman, "The water use of sweet sorghum and development of crop coefficients," Irrigation and Drainage, vol. 64, no. 1, pp. 93-104, 2015.

[8] G. S. McMaster and W. W. Wilhelm, "Phenological responses of wheat and barley to water and temperature: improving simulation models," Journal of Agricultural Science, vol. 141, no. 2, pp. 129-147, 2003.

[9] T. A. Howell, S. R. Evett, J. A. Tolk, K. S. Copeland, and T. H. Marek, "Evapotranspiration, water productivity and crop coefficients for irrigated sunflower in the U.S. Southern High Plains," Agricultural Water Management, vol. 162, pp. 33-46, 2015.

[10] R. López-Urrea, A. Montoro, and T. J. Trout, "Consumptive water use and crop coefficients of irrigated sunflower," Irrigation Science, vol. 32, no. 2, pp. 99-109, 2014.

[11] R. López-Urrea, A. Montoro, F. Mañas, P. López-Fuster, and E. Fereres, "Evapotranspiration and crop coefficients from lysimeter measurements of mature 'Tempranillo' wine grapes," Agricultural Water Management, vol. 112, pp. 13-20, 2012.

[12] C. Bautista-Capetillo, M. Zavala, and A. Martínez-Cob, "Using thermal units for crop coefficient estimation and irrigation scheduling improves yield and water productivity of corn (Zea mays L.)," Journal of Irrigation and Drainage Engineering, vol. 139, no. 3, pp. 214-220, 2013.

[13] D. A. Tisot, A. H. N. Maia, D. Dourado Neto et al., "Models of temporal variation pattern of the common bean crop productivity components characterized by degree-days," Revista Brasileira de Agrometeorologia, vol. 13, no. 1, pp. 81-89, 2005 (Portuguese).

[14] FAO, Report, Food and Agricultural Organization, United Nations, Statistical Division, FAOSTAT, 2015, http://faostat3.fao .org/home/E.

[15] G. A. de Medeiros, L. A. Daniel, J. R. F. Lucarelli, and F. A. G. V. Reis, "Influence of the soil tillage and management in a Latossolo vermelho on its physical and hydrics properties," Geociências, vol. 28, no. 4, pp. 453-465, 2009 (Portuguese).

[16] G. A. de Medeiros, L. A. Daniel, J. R. F. de Lucarelli et al., "Restoration of a degraded area using soil tillage systems in Campinas, São Paulo, Brazil," WIT Transactions on Ecology and the Environment, vol. 162, pp. 243-252, 2012.

[17] R. G. Allen, L. S. Pereira, D. Raes, and M. Smith, Crop Evapotranspiration: Guidelines for Computing Crop Water Requirements, FAO, Rome, Italy, 1998.

[18] F. Fernández, P. Geptz, and M. López, "Etapas de desarollo de la planta frijol," in Frijol: Investigación y Producción, M. López, F. Fernández, and A. Van Schoonhoven, Eds., pp. 61-78, PNUD/CIAT, Cali, Colo, USA, 1985.

[19] G. A. de Medeiros, F. B. Arruda, E. Sakai, and M. Fujiwara, "The influence of crop canopy on evapotranspiration and crop coefficient of beans (Phaseolus vulgaris L.)," Agricultural Water Management, vol. 49, no. 3, pp. 211-224, 2001.

[20] G. A. de Medeiros and F. B. Arruda, "Adaptation and evaluation of evapotranspirometer to determine the basal crop coefficient (kcb) of beans," Irriga, vol. 4, no. 2, pp. 92-103, 1999 (Portuguese).

[21] G. A. de Medeiros, F. B. Arruda, and E. Sakai, "Relations between crop coefficient and vegetative ground cover of beans: errors involved and analyses for different time intervals," Acta 
Scientiarium Agronomy, vol. 26, no. 4, pp. 513-519, 2004 (Portuguese).

[22] G. A. de Medeiros, F. B. Arruda, and E. Sakai, "Crop coefficient for irrigated beans derived using three reference evaporation methods," Agricultural and Forest Meteorology, vol. 135, no. 14, pp. 135-143, 2005.

[23] R. G. Allen and L. S. Pereira, "Estimating crop coefficients from fraction of ground cover and height," Irrigation Science, vol. 28, no. 1, pp. 17-34, 2009. 


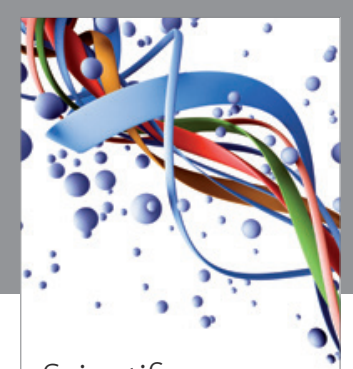

Scientifica
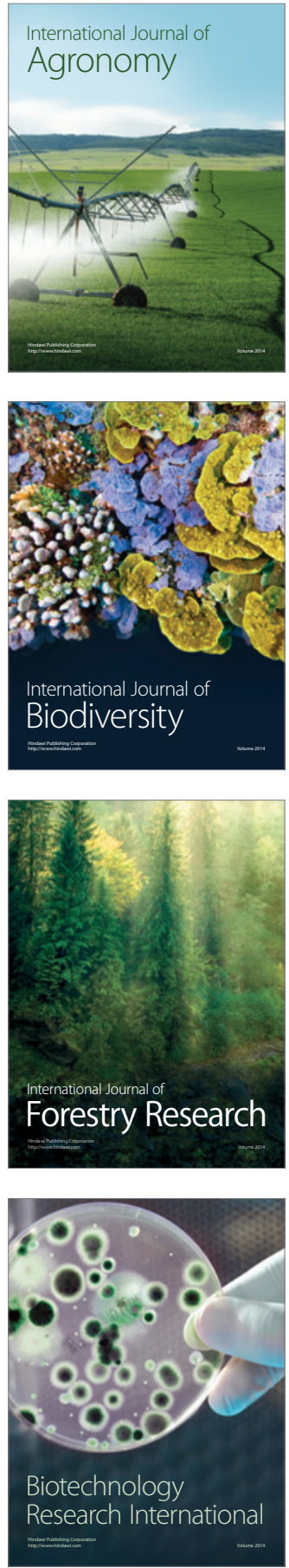
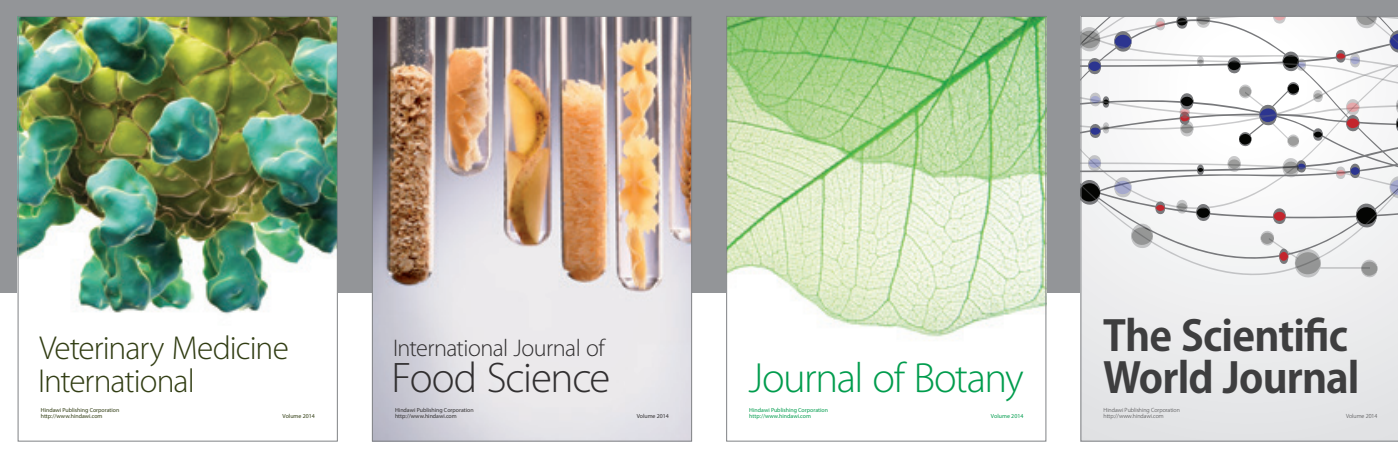

The Scientific

\section{World Journal}

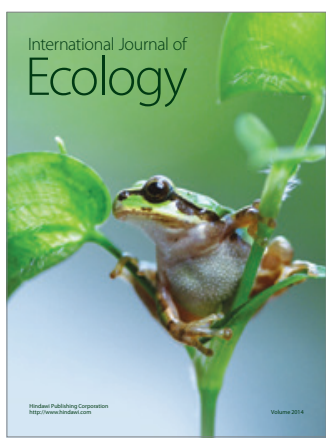

\section{Hindawi}

Submit your manuscripts at

http://www.hindawi.com
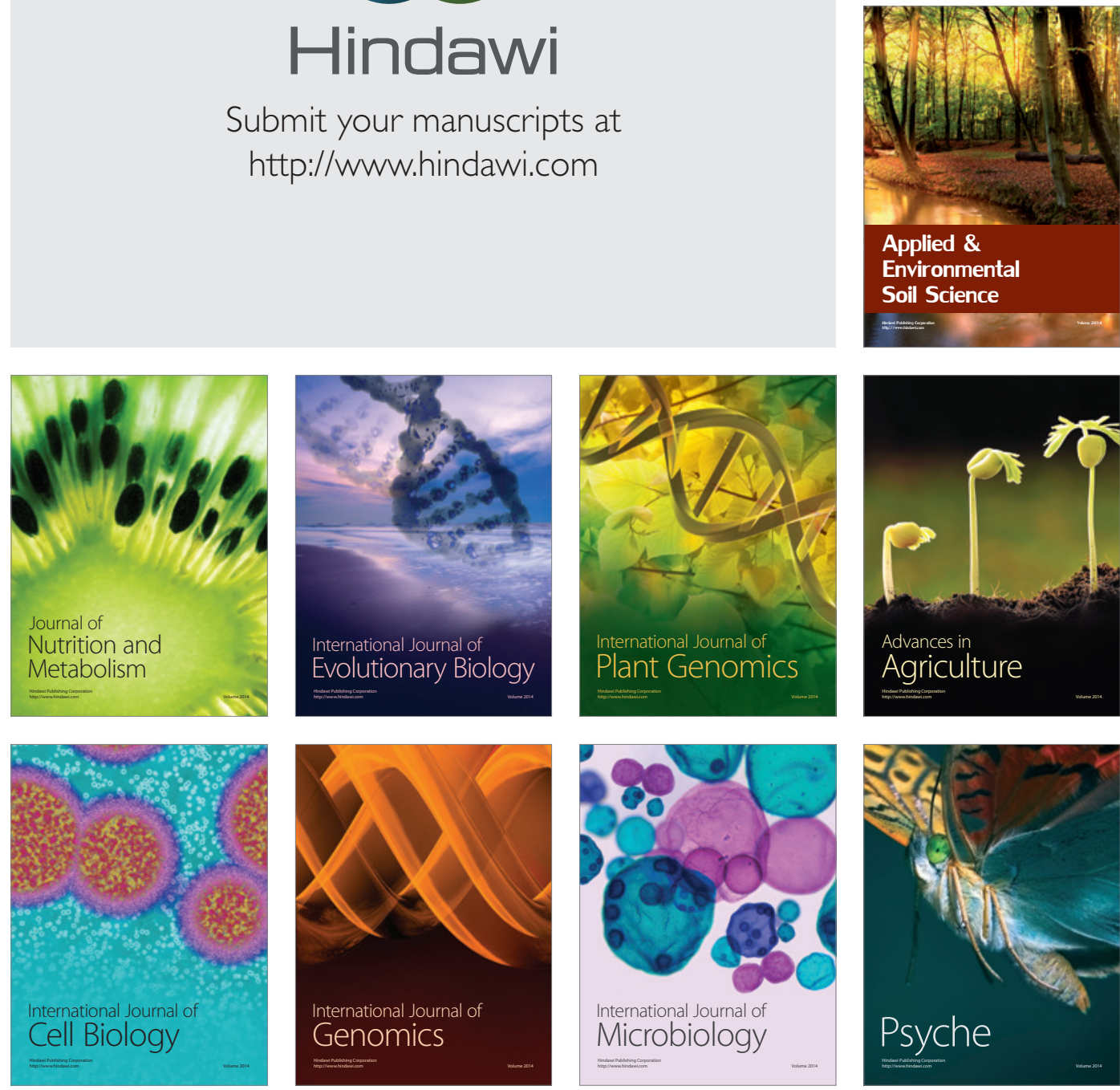
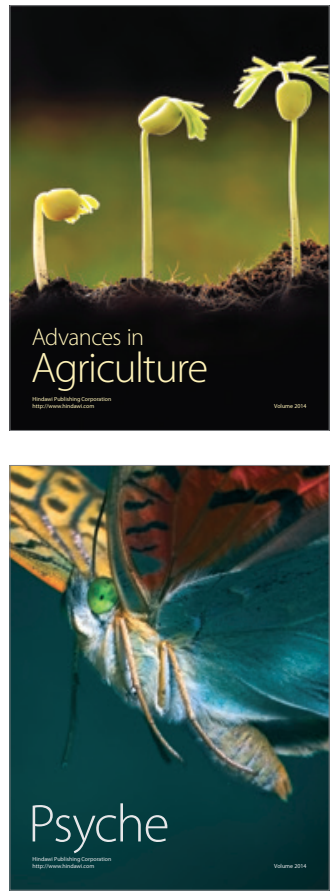